\title{
Physicochemical water quality characteristics in relation to land use pattern and point sources in the basin of the Dongjin River and the ecological health assessments using a fish multi-metric model
}

Geon-Su Jang ${ }^{1,2}$ and Kwang-Guk $A n^{1 *}$

\begin{abstract}
Background: Little is known about how chemical water quality is associated with ecological stream health in relation to landuse patterns in a watershed. We evaluated spatial characteristics of water quality characteristics and the ecological health of Dongjin-River basin, Korea in relation to regional landuse pattern. The ecological health was assessed by the multi-metric model of Index of Biological Integrity (IBI), and the water chemistry data were compared with values obtained from the health model.

Results: Nutrient and organic matter pollution in Dongjin-River basin, Korea was influenced by land use pattern and the major point sources, so nutrients of TN and TP increased abruptly in Site 4 (Jeongeup Stream), which is directly influenced by wastewater treatment plants along with values of electric conductivity (EC), bacterial number, and sestonic chlorophyll-a. Similar results are shown in the downstream (S7) of Dongjin River. The degradation of chemical water quality in the downstream resulted in greater impairment of the ecological health, and these were also closely associated with the landuse pattern. Forest region had low nutrients (N, P), organic matter, and ionic content (as the EC), whereas urban and agricultural regions had opposite in the parameters. Linear regression analysis of the landuse (arable land; $A_{L}$ ) on chemicals indicated that values of $A_{L}$ had positive linear relations with TP $\left(R^{2}=0.643, p<0.01\right)$, TN $\left(R^{2}=0.502, p<0.05\right)$, BOD $\left(R^{2}=0.739, p<0.01\right)$, and suspended solids $\left(S S ;\left(R^{2}=0.866\right.\right.$, $p<0.01)$, and a negative relation with TDN:TDP ratios $\left(R^{2}=0.719, p<0.01\right)$.
\end{abstract}

Conclusions: Chemical factors were closely associated with land use pattern in the watershed, and these factors influenced the ecological health, based on the multimetric fish IBI model. Overall, the impairments of water chemistry and the ecological health in Dongjin-River basin were mainly attributes to point-sources and land-use patterns.

Keywords: Dongjin River, Land use, Stream health, Multi-metric fish model

\footnotetext{
*Correspondence: kgan@cnu.ac.kr

'Department of Biological Science, Chungnam National University, Daejeon

34134, South Korea

Full list of author information is available at the end of the article
} 


\section{Background}

The basin of the Dongjin River is made of one Dongjin River and two streams of Gobu and Jeongeup. The source of water is from Mt. Naejang, Jeonbuk Province, and the stream has a basin area of $1129 \mathrm{~km}^{2}$ and $52.4 \mathrm{~km}$ of total river length. The basin is located in the agricultural area located in the plain of rice paddy in Kimjae, Buahn, and Shintaein regions. The stream water is largely used by drinking water and agricultural irrigation along with partial use of industrial water. For these reasons, previous studies pointed out that water quality is degradated in the downstream regions, which are directly influenced by the wastewater treatment plants or agricultural crop-cultivation in the wide ranges of rice paddy (Seo et al. 2001; Jung et al. 2009; Seong and Park 2012). For these reasons, basin management is important for maintaining chemical water quality and the aquatic ecosystem.

Researches in the basin of the Dongjin River showed that intensive agricultural activities and constructions increased high nitrogen phosphorus in the streams and suspended solids (Uhm et al. 2000, Son et al. 2012). Also, runoff in small residential or urban area increased inputs of hazard chemicals, nutrients, and organic matter (Ko et al. 2001, Won et al. 2002, Lee et al. 2005) along with the sediments from the watershed (Yun et al. 2002, Lee et al. 2004). These activities increased sediment transport or deposition in the downstreams, and this forced to stream dredging, resulting in physical degradation of streams throughout the habitat modifications (Barbour et al. 1999, Morley and Karr 2002). Such factors changed nutrient ratios and nutrient regime (Lee and Shin 2013) and thus led to changes in the compositions of the biotic community inhabiting the stream and decreases in the biodiversity (Yeom et al. 2000). Under these circumstances, the key symptoms showing alterations of ecological structures and functions were decreases of fish species diversity (Kim et al. 2009), dominance of tolerant species (Kim and Lee 2001, Desirree et al. 2006, Walton et al. 2007), increased proportion of omnivore species, decreased number of sensitive species (Barbour et al. 1999), and increased abnormalities of fish (Yeom et al. 2000). The alterations of the ecological function resulted in massive impairment of overall ecological stream health (Karr 1981, Karr et al. 1986, US EPA 1993, An and Kim 2005, An et al. 2006). Karr et al. (1986) pointed out that development of stream assessment methodology throughout measuring not only chemical conditions but also indicator species characteristics is urgent for the diagnosis of the ecological health or the multilateral restoration of streams and rivers. For these reasons, assessments of ecological stream health, based on the index of biological integrity model (Karr 1981), were widely applied to numerous countries in relation to water chemistry or land use pattern.
The objectives of this study were to analyze the physicochemical water quality and fish compositions in the basin of the Dongjin River and elucidate their relations to land use pattern and key point sources such as wastewater treatment plants near the streams. In addition, a multi-metric model of the index of biological integrity (IBI), based on fish assemblages, was applied in the three major streams of the basin for the diagnosis of current ecological health conditions.

\section{Methods}

\section{Descriptions of study sites}

Nine sampling sites belong to three streams in the basin; four sites of site 1-site 4 belong to the Jeongeup Stream, three sites of S5-S7 belong to the Dongjin River, and the remaining two sites of site 8 and site 9 belong to the Gobu Stream. Especially, site 4 is directly influenced by effluents of sewage disposal plants (Wp-1, Wp-2), and this water influences S7 in the downstream region. Morphological alterations of the stream bed are kept to a minimum in the headwater reach (S1-S3, S5), while habitat structure is more and more degraded due to agricultural activities or sewage disposal plants in the downstream reaches $(\mathrm{S} 7, \mathrm{~S} 4, \mathrm{~S} 9)$.

\section{Water quality parameters and analysis}

Chemical dataset, based on monthly-based measurement, at nine sites (S1-S9) were obtained from the National Water Quality Monitoring Program (NWQMP) of the Ministry of Environment, Korea (MEK) during January 2009-December 2012. The parameters analyzed were dissolved oxygen (DO), $\mathrm{pH}$, water temperature, bacterial most probable number (MPN), electric conductivity (EC), suspended solids (SS), biochemical oxygen demand (BOD), and chemical oxygen demand (COD). Also, nutrients such as total nitrogen (TN), total phosphorus (TP), nitrate-nitrogen $\left(\mathrm{NO}_{3}-\mathrm{N}\right)$, and ammonianitrogen $\left(\mathrm{NH}_{4}-\mathrm{N}\right)$ were included in the analysis along with ratios of TDN to TDP (total dissolved nitrogen to total dissolved phosphate) and chlorophyll-a (CHL-a) as a measure of primary productivity. We analyzed the spatial patterns from upstream to downstream sites of the parameters using the data.

\section{Data analysis of land use pattern}

Land use pattern in the basin of the Dongjin River was analyzed using a land-coverage dataset of Geological Information System (GIS) in 2010. According to the original GIS data of land cover, the land use was categorized as a residential (urban) area, arable (agricultural) area, forest area, grassland area, wetland area, no-grass area, and the water-covered area. The basin was mainly composed of arable (agricultural) area and forest area with little amount of others. The land use pattern in this 
study, thus, was expressed as a pick cell of percent arable (agricultural) area and forest area, respectively.

\section{Fish sampling and ecological analysis of fish compositions}

Nine sites were selected from the 2012 data file of the basin of the Dongjin River. Fish sampling was followed by the wading method of An et al. (2002). In each sampling site, all habitat types including riffle, run, and pool were sampled in an upstream direction for a distance of $200 \mathrm{~m}$ during $50 \mathrm{~min}$. At each site, we used sampling gears of hand net $(5 \times 5 \mathrm{~mm})$ and casting net $(5 \times 5 \mathrm{~mm})$ to collect fishes. All fishes were identified and released at the sampling locations, but some ambiguous specimens to identify were preserved in $10 \%$ formalin. Guild analyses of sensitive and tolerant species were based on the previous regional studies of the MEK (An et al. 2006).

\section{Ecological health assessments using a multi-metric model} (IBI)

A multi-metric model of the IBI was applied to the basin of the Dongjin River for stream health assessments of the Jeongeup Stream, Dongjin River, and Gobu Stream. The IBI model was modified from a 10-metric to an 8metric model (An et al. 2002), and the original metric was based on Karr (1981) and Barbour et al. (1999) in North America. The metrics (M) were composed of three major groups such as species richness and composition, trophic composition, and fish abundance and health condition.
Metric scores of 1,3 , or 5 were assigned to each of the raw metric values after the approach of US EPA (Barbour et al. 1999). These scores were then summed to obtain a sitespecific model value that ranged from 10 to 40 , and five classes (excellent, 38-40; good, 32-34; fair, 26-29; poor, 18-22; and very poor, $\leq 14$ ) were used for the evaluation.

\section{Results and discussion}

\section{Water chemistry in the basin}

Water chemistry, based on physicochemical data of 2009-2012, showed spatial variations depending on the stream or the location of point source (sewage disposal plants). Dissolved oxygen (DO), $\mathrm{pH}$, and water temperature had little differences within each water body of the Jeongeup Stream, Dongjin River, and Gobu Stream (Fig. 1a-c). Concentrations of DO averaged $10.2 \mathrm{mg} \mathrm{L}^{-1}$ and ranged from 9.4 to $10.9 \mathrm{mg} \mathrm{L}^{-1}$, and $\mathrm{pH}$ averaged 7.8 and ranged from 6.5 to 8.3 , indicating excellent conditions (rank: $I_{\mathrm{a}}$ ) by the criteria of the MEK. In the meantime, $\mathrm{pH}$ was significantly greater in the Gobu Stream than in the Jeongeup Stream (Fig. 1b). In contrast, total number of Escherichia coli, EC, and SS showed typical longitudinal gradients from the upstream to downstream reach (Fig. 1d-f). This outcome indicates that water quality in these parameters decreases toward the downstream due to point sources and non-point sources. Especially, the downstream (S4) of the Jeongeup Stream was most pronounced in the impairments of water quality due to effluents from two sewage disposal plants. Values

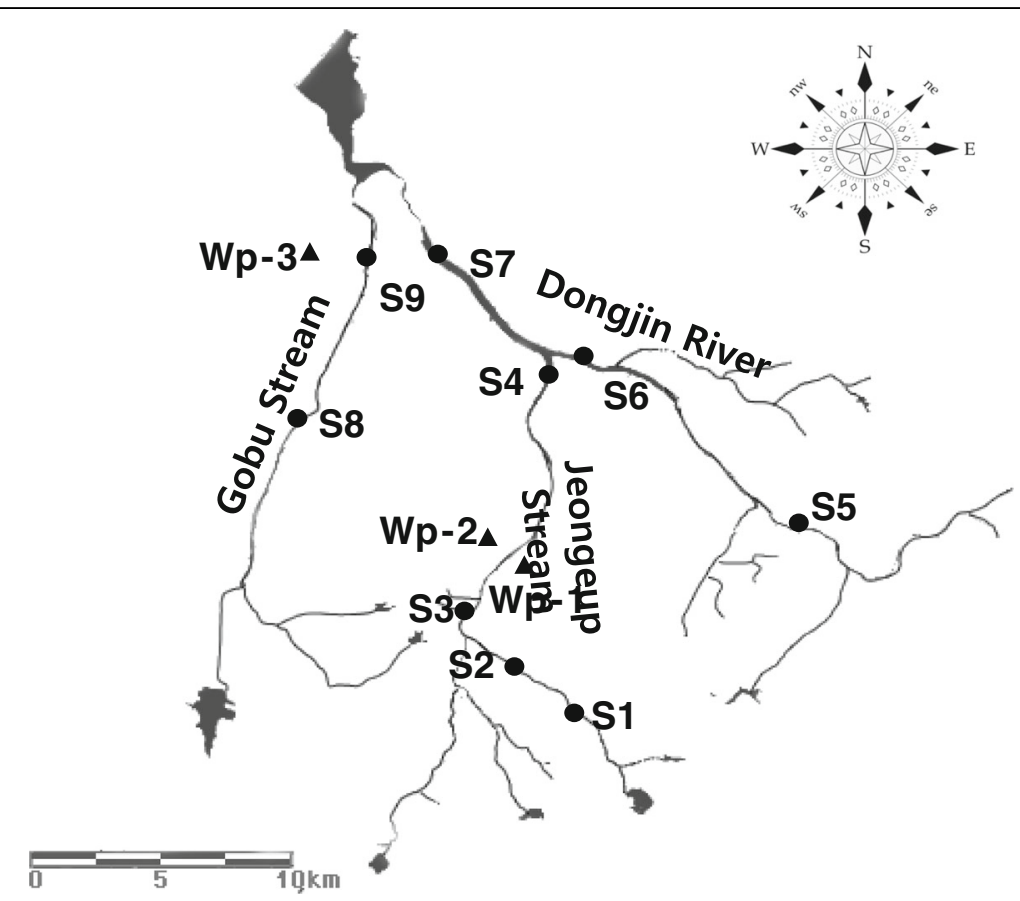

Fig. 1 Sampling locations (S1 - S9) from three waterbodies of Jeongeup Stream, Dongjin River, and Gobu Stream in the basin of Dongjin River. The mark in the figure are as follows ( $\bullet$ : sampling site, $\mathbf{\Delta}$ : sewage treatment plants of Wp-1, Wp-2, and Wp-3) 
of $E$. coli, EC, and SS were greater up to $240-2800 \%$ in the downstream (S4) than the upstream (S1; Fig. 1d-f). Similarly, the downstream (S7) of the Dongjin River had worst water quality in E. coli, EC, and SS among the three sites (S5-S7).

Nutrient (N, P) and organic matter concentrations showed typical downstream increasing patterns in all the three streams of the Jeongeup Stream, Dongjin River, and Gobu Stream (Fig. 2). Mean TN was $>2.0 \mathrm{mg} \mathrm{L}^{-1}$ in all sampling sites, and the major compositional of nitrogen was $\mathrm{NO}_{3}-\mathrm{N}$ rather than $\mathrm{NH}_{4}-\mathrm{N}$ (Fig. 2). These results indicate that nitrogen in the all streams is rich, and soluble nitrogen is high in the basin. Under this circumstance, nitrogen may not be limited to sestonic algal or periphyton growth, unlike other streams of the USA, Canada, and Europe. In the Jeongeup Stream, mean
$\mathrm{TN}$ was greater than twofold in the downstream (S4) than in the upstream $(\mathrm{S} 1) . \mathrm{NO}_{3}-\mathrm{N}$ and $\mathrm{NH}_{4}-\mathrm{N}$ also showed a trend of downstream increase in the Jeongeup Stream (Fig. 2). In the meantime, TP averaged $0.107 \mathrm{mg} \mathrm{L}^{-1}$ (range $0.027-0.242 \mathrm{mg} \mathrm{L}^{-1}$ ) in the basin of the Dongjin River and showed a typical pattern of downstream increase like the concentrations of TN. Thus, the mass ratios of TDN and TDP showed a maximum 1128 in the upstream (S1) and a minimum 12.7 in the downstream (S4) of the Jeongeup Stream (Fig. 2g). The high N:P ratios indicated that phosphorus may be a potential key nutrient limiting and regulating the sestonic algal growth in the upstreams (S1 and S5). In fact, concentrations of CHL-a in the upstream sites ( $\mathrm{S} 1$ and $\mathrm{S} 5$ ) were minimum due to high $\mathrm{N}: \mathrm{P}$ ratios in each stream (Fig. $2 \mathrm{~g}, \mathrm{~h}$ ). In contrast, maximum CHL-a in the downstreams (S4 and S7)
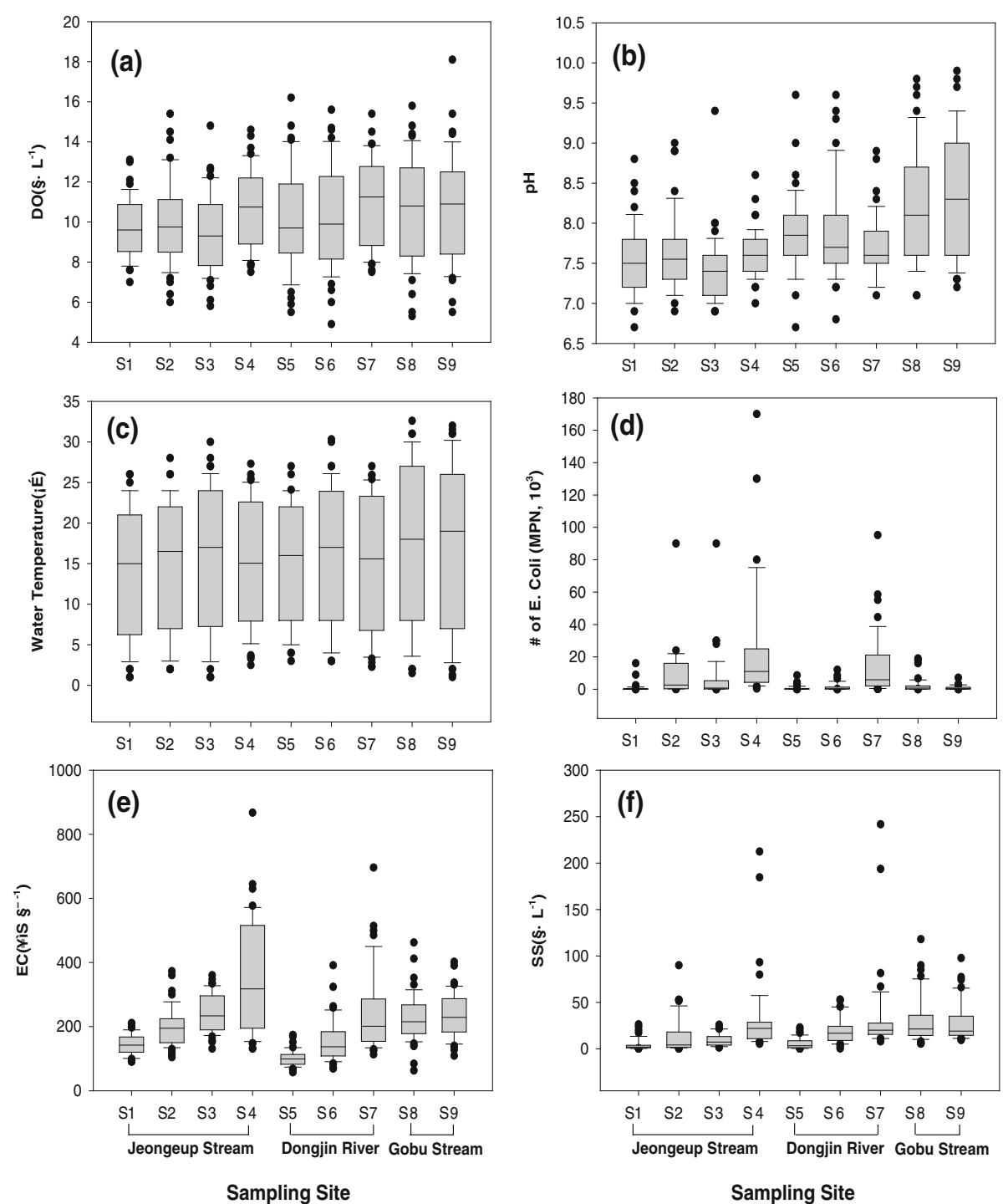

Fig. 2 Physico-chemical water quality of dissolved oxygen (DO), pH, water temperature, total number of E. coli (MPN), electric conductivity (EC), and suspended solids (SS) in the basin of Dongjin River 
increased up to $160 \mu \mathrm{g} \mathrm{\textrm {L } ^ { - 1 }}$ (Jeongeup Stream) and $68 \mu \mathrm{g} \mathrm{L}^{-1}$ (Dongjin River; Fig. 2h), indicating a high primary production and eutrophication (Debora et al. 2006). This was mainly attributed to the runoff of nutrient-rich water from sewage disposal plants. This fact is supported by high nutrients $(\mathrm{N}, \mathrm{P})$, high organic matter (BOD, COD), and high CHL-a in the sites of S4 and S9. Organic matter pollution, based on BOD and COD showed a similar pattern with the nutrients.

\section{Fish composition analysis}

Total number of fish species and total number of individuals was 33 and 348 in the basin of the Dongjin River, respectively (S2 was not included; Table 1 ). As shown in

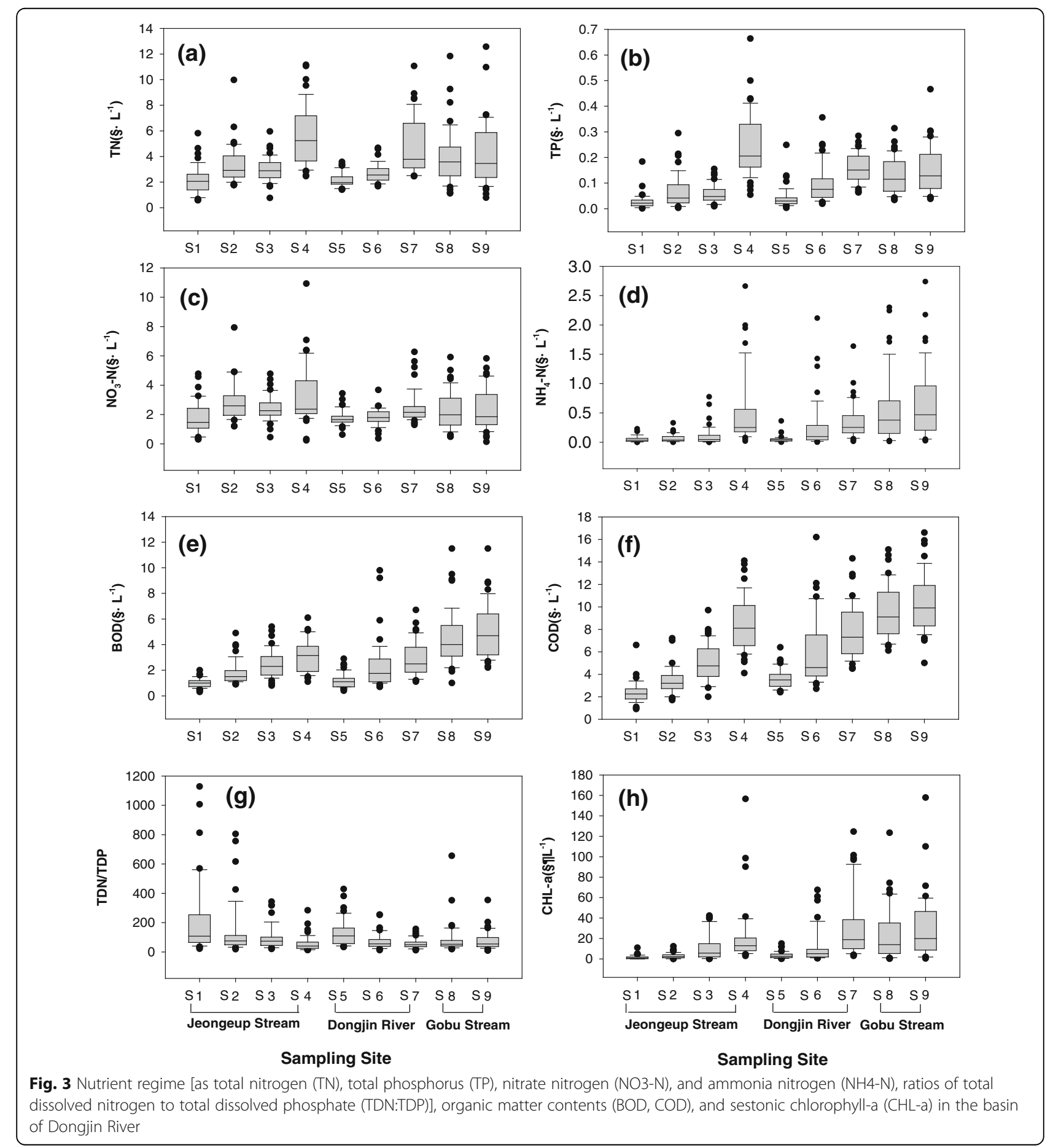


Table 1, tolerance guilds were categorized as tolerant, intermediate, and sensitive species and trophic guilds were categorized as omnivore, insectivore, and carnivore species. The most dominant species was Carassius auratus, which is composed of $34.2 \%$ of the total and is a tolerant and omnivore species in the fish guilds (Table 1). These characteristics indicate ecological degradations or impairment of the basin as suggested in the ecological indicator analyses of Karr (1981) and Barbour et al. (1999). According to the analysis of tolerance guilds, there were the tendency of typical downstream decreases in the proportions of sensitive species and downstream increases in the proportions of tolerant species. Also, in trophic guilds, there were the tendency of typical downstream decreases in the proportions of insectivore species and downstream increases in the proportions of omnivore species. The ecological guild analysis was matched well with nutrients $(\mathrm{N}, \mathrm{P})$ and organic matter analysis in the basin. In other words, the pattern of fish composition, based on the ecological guilds, was directly influenced by water chemistry; thus, organic matter pollution or nutrient enrichments from the watershed resulted in decreases in the proportions of sensitive and insectivore species and increases in the tolerant and omnivore species (Barbour et al. 1999). In the meantime, bluegill (Lepomis macrochirus), largemouth bass (Micropterus salmoides), and gold fish (Carassius cuvieri) occurred in the three sites S3 (12 individuals), S8 (1), and S9 (1; Table 1).

\section{Land use pattern in the sampling sites}

In the basin of the Dongjin River, the land use pattern analyzed using the land-coverage dataset of the GIS showed that the proportion of forests in the sampling sites was nearly an inverse relation with the proportion of arable land. One of the predominant phenomena was that relative proportion of arable (agricultural) land increased from the upstream to downstream site and in contrast, percent forest cover decreased from the upstream to downstream (Fig. 3). In the Jeongeup Stream, percent forest was nearly $70 \%$ in S1, 40-50\% in S2 and $\mathrm{S} 3$, and $<10 \%$ in S4 (Fig. 3). In contrast, the proportion of arable land increased from the upstream to the downstream site. In the Jeongeup Stream, percent arable land was $<20 \%$ in S1 and $25-38 \%$ in S2 and S3 along with $>70 \%$ in S4, higher percent forest in the upstream, and higher percent arable land in the downstream (Fig. 3). Especially, the proportion of arable land was 73-86 \% in sites S4, S6, and S7, while the proportion of forest cover was $>60 \%$ in the upstream sites S1 and S5 (Fig. 3).

\section{Relations of land use pattern to water quality}

The land use pattern in the basin was closely associated with nutrient regimes, organic matter contents, and other parameters (Figs. 4 and 5). Linear regression analysis of the land use (arable land; $A_{\mathrm{L}}$ ) on chemical parameters indicated that values of $A_{\mathrm{L}}$ had positive linear relations with TP $\left(R^{2}=\right.$ $0.643, p<0.01)$, TN $\left(R^{2}=0.502, p<0.05\right)$, BOD $\left(R^{2}=0.739\right.$, $p<0.01)$, and SS $\left(R^{2}=0.866, p<0.001\right)$ and a negative relation with TDN:TDP ratios $\left(R^{2}=0.719, p<0.01\right.$; Fig. 4).

In the meantime, $A_{\mathrm{L}}$ values had no significant relation with EC $\left(R^{2}=0.312, p=0.118\right)$. As shown in Fig. 4, when the proportion of the arable land was $>70 \%$, nutrients (TN, TP), organic matter content, and SS increased largely, suggesting that intensive farming activities resulted in eutrophication of the basin. Similarly, linear regression analysis of the forest cover $\left(F_{\mathrm{C}}\right)$ on chemical parameters indicated that values of $F_{\mathrm{C}}$ had negative linear relations with TP $\left(R^{2}=0.683, p<0.01\right)$, TN $\left(R^{2}=0.566, p<0.05\right)$, BOD $\left(R^{2}=0.709, p<0.01\right)$, and SS $\left(R^{2}=0.867, p<0.001\right)$ and a positive relation with TDN:TDP ratios $\left(R^{2}=0.773, p<0.01\right.$; Fig. 5). These outcomes suggest that higher proportions of forest cover reduce the nutrients, organic matters, and SS (inorganic + organic matters) from the watersheds and thus, the forest may act as a filter for nutrient leaching from the soil.

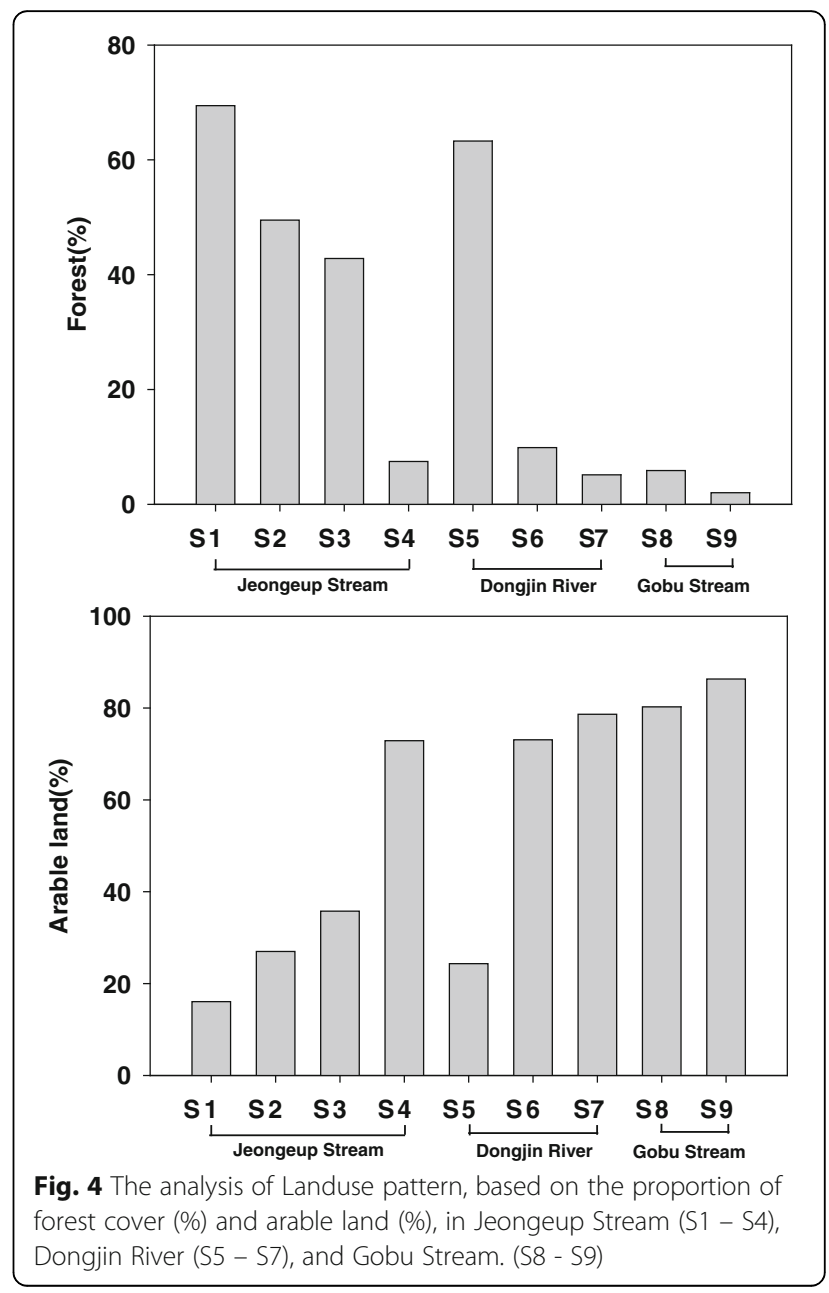



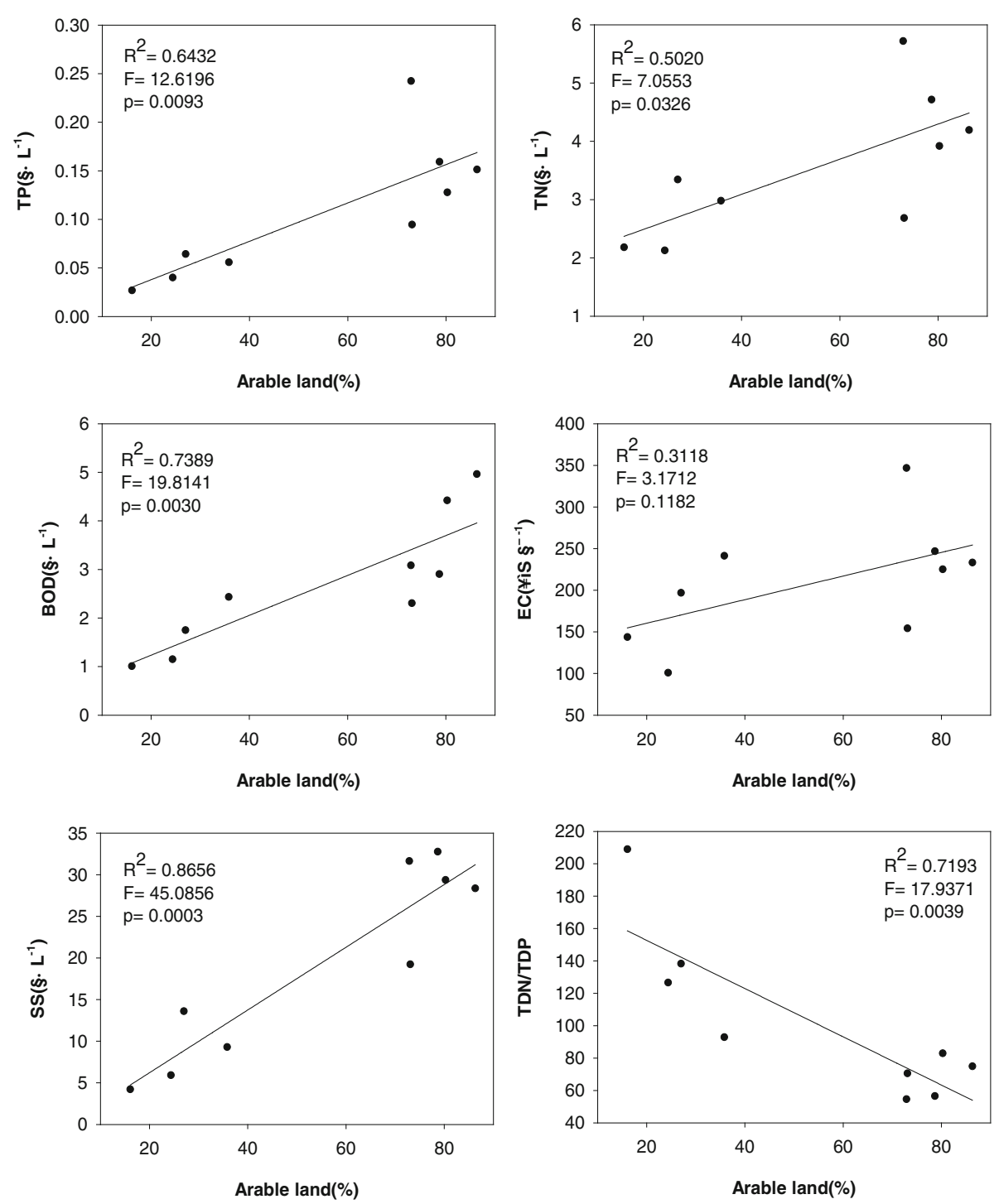

Fig. 5 Linear regression analysis of chemical parameters (TP, TN, BOD, EC, SS, ratios of TDN:TDP) against the proportion of arable land in the basin

\section{Biological integrity model for the diagnosis of stream ecosystem health}

The model values of the IBI varied from 10 to 22 depending on the sampling site of the basin of the Dongjin River and the mean IBI was $15(n=8$; Table 2$)$. Thus, the stream health in the basin, based on the mean IBI, was judged as a "poor-very poor" condition according to the modified criteria of IBI (An et al. 2006). The values of IBI decreased from the upstream of S1 (20, poor condition) to downstream of S4 (14, very poor condition) in the Jeongeup Stream, and this pattern was similar to the IBI values of the Dongjin River with 22 (poor condition) in the upstream (S5) and 10 (very poor) in the downstream (S7; Table 2). Three water bodies of the Jeongeup Stream, Dongjin River, and Gobu Stream showed poor to very poor health conditions (Table 2). This indicates that ecological degradation is evident in the basin, and also this was supported by the dominance of the tolerant species and dominant omnivore species. The analysis of external DELT anomalies showed that one individual of $C$. auratus had skin lesion (LE) in the sampling site S7 (Dongjin River) where IBI value was minimum (10). The external anomaly and minimum IBI in the S7 indicate the impairment of the downstream site along with the site S4, even if the percent of the anomalies was not high like $C$. auratus (24\%) in the Ohio streams (Sanders et al. 1999). This study supports the finding that chemical degradation by sewage treatment plants and agricultural farms resulted in external anomaly and low IBI. 
Relations of fish trophic compositions and tolerance to chemical water quality

Previous studies (Hughes and Gammon 1987) pointed out that fish trophic compositions and tolerance of fish are closely associated with chemical water quality (Karr 1981, Barbour et al. 1999). In this study, regression models were developed using an inverse first-order equation. Relative proportion of omnivore fish species was increased by increases of TP $\left(R^{2}\right.$ $=0.890, p<0.001)$, TN $\left(R^{2}=0.765, p<0.01\right)$, and BOD $\left(R^{2}=0.878, p<0.001\right.$; Fig. 6$)$. In contrast, the proportion of insectivore species was declined by increases of TP $\left(R^{2}=0.953, p<0.001\right)$, TN $\left(R^{2}=0.698, p<0.01\right)$, and BOD $\left(R^{2}=0.875, p<0.001\right.$; Fig. 6$)$. This result is supported by previous studies (Barbour et al. 1999, An et al. 2002) that water quality is the key factor determining the trophic compositions of fish in the water bodies.
In the analysis of tolerance guilds on water quality (nutrients, organic matter), the proportion of tolerant species, as a number of individuals, was increased by increases of $\operatorname{TN}\left(R^{2}=0.760, p<0.01\right)$ and $\operatorname{BOD}\left(R^{2}=\right.$ $0.554, p<0.05)$ but had no significant relation with TP $(p>0.05$; Fig. 7$)$. In contrast, the proportion of sensitive species had an inverse function with TP $\left(R^{2}=0.921\right.$, $p<0.001)$, TN $\left(R^{2}=0.712, p<0.01\right)$, and $\operatorname{BOD}\left(R^{2}=\right.$ 0.940, $p<0.001$; Fig. 7).

\section{Relations of ecological stream health fish to water chemistry and land use pattern}

Regression analysis of water quality and land use parameters on the IBI showed that ecological stream health was directly influenced by the land use pattern of forest cover and arable land (Fig. 8). Probably, forest may have
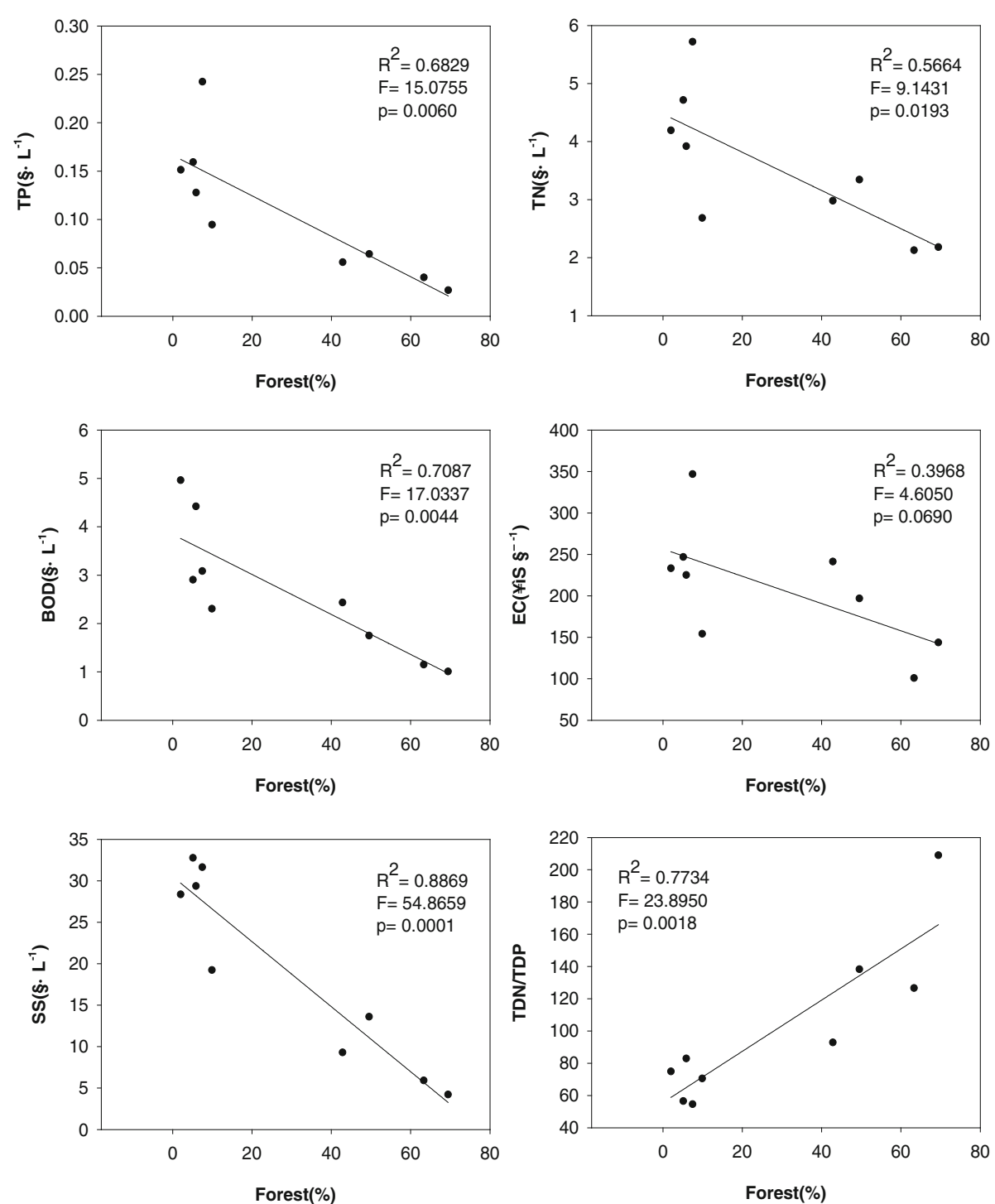

Fig. 6 Linear regression analysis of chemical parameters (TP, TN, BOD, EC, SS, ratios of TDN:TDP) against the proportion of forest cover in the basin 

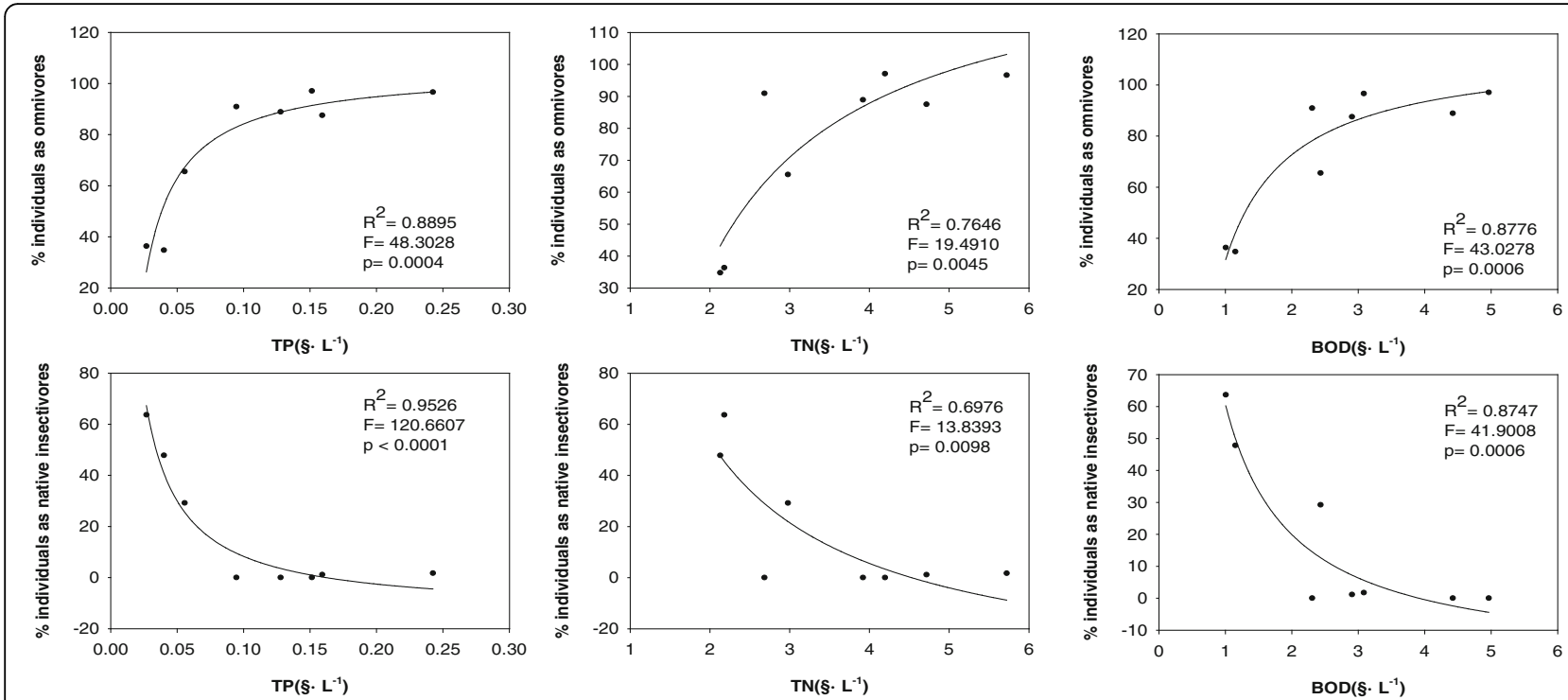

Fig. 7 Regression models, based on inverse first-order equation, of trophic compositions of omnivores (\%) and insectivore species (\%) against the concentrations of TP, TN and BOD

a role of filtration (sink) on nutrients $(\mathrm{N}, \mathrm{P})$ and SS; thus, the increases in the proportion of forest land resulted in better ecological stream health. In contrast, arable land may be a source of non-point source for nutrients and SS; thus, the increases in the proportion of arable land resulted in worse ecological stream health. These facts are supported by the regression analysis in Fig. 8. The regression analysis of TP and TN on the IBI model values showed that the variation of IBI values was explained 70.7 and $62.1 \%$ by concentration of TP $\left(R^{2}=\right.$ $0.707, p<0.01)$ and TN $\left(R^{2}=0.621, p<0.05\right)$, respectively (Fig. 8).
Also, the regression analysis of $\mathrm{BOD}$ and $\mathrm{EC}$ on the IBI values showed that $71.9 \%$ in the variation of IBI values was accounted by the variation of BOD $\left(R^{2}=\right.$ $0.719, p<0.01)$ and that $53.9 \%$ in the variation of IBI was accounted by the variation of conductivity $\left(R^{2}=\right.$ $0.539, p<0.05$ ) (Figs. 8 and 9).

\section{Conclusions}

In this study, physicochemical water quality and fish compositions were analyzed along with a diagnosis of ecological health in relation to land use pattern or key point sources. Overall, this research suggests that

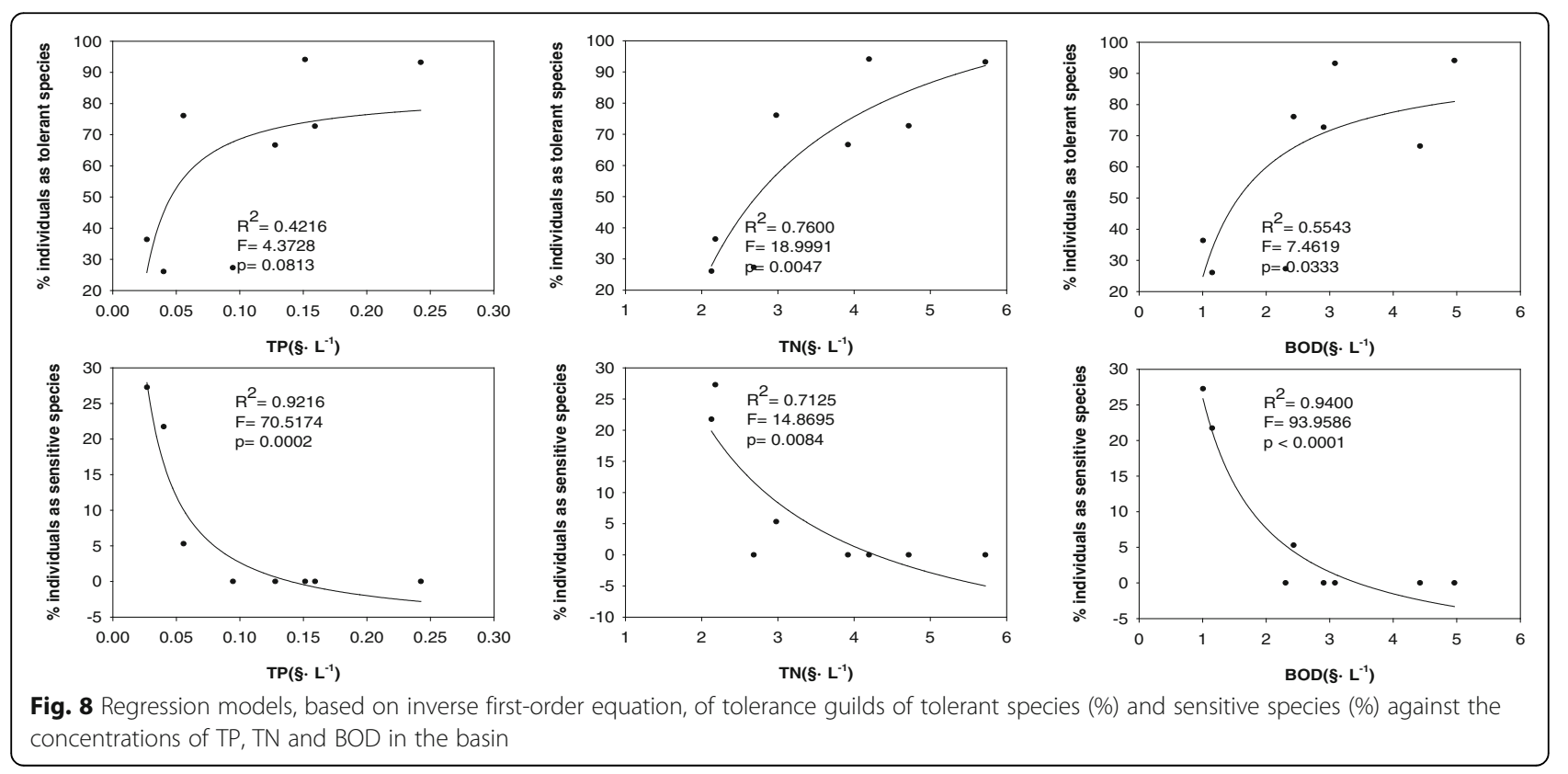



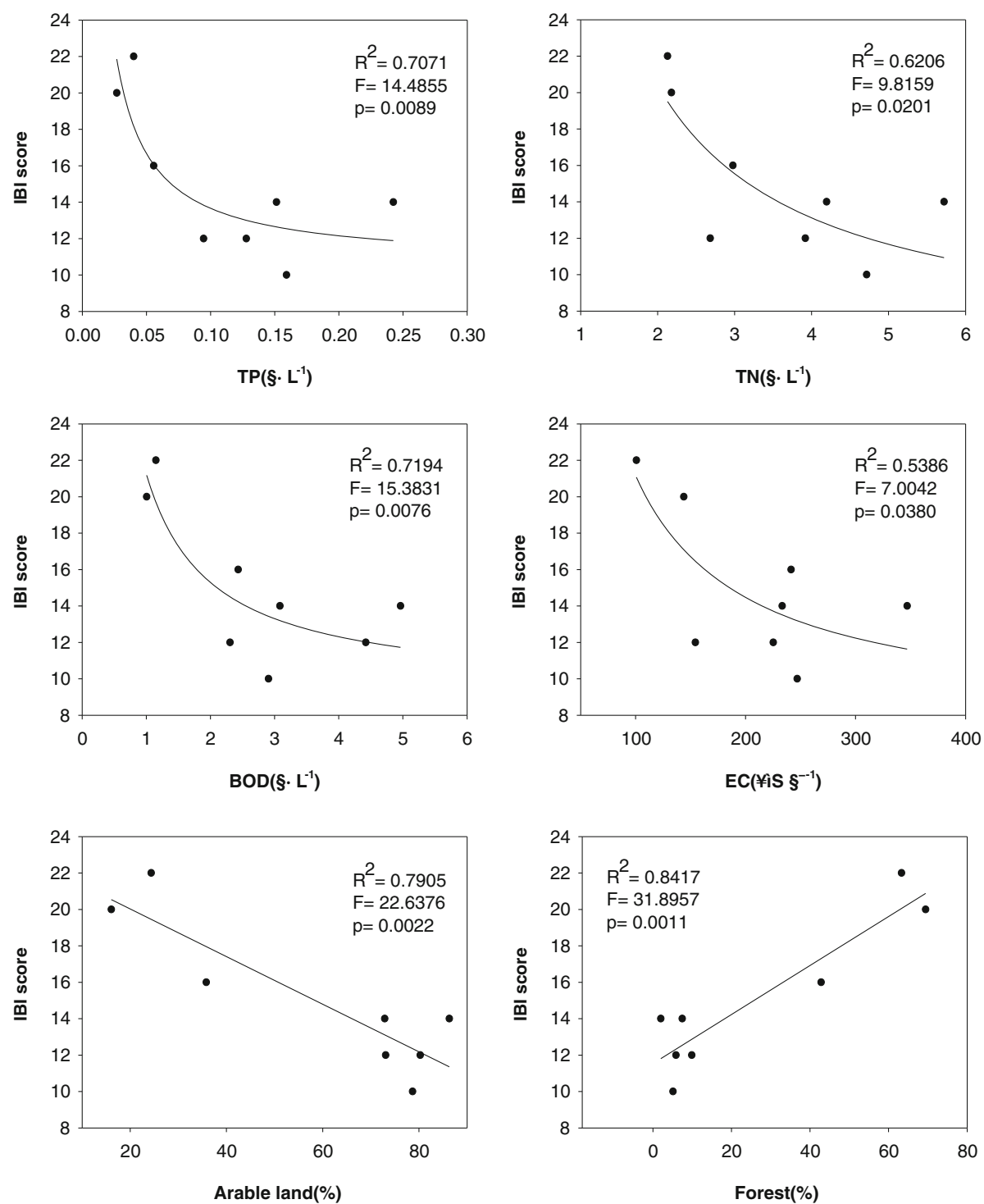

Fig. 9 Regression models of the Index of Biological Integrity (IBI) against the chemical parameters (TP, TN and BOD) and landuse pattern (arable land and forest cover)

nutrient regime, organic matters (BOD, COD), and total number of $E$. coli were directly influenced by point sources of sewage wastewater plants and then also determined by land use pattern, based on the proportion of arable land and forest cover. This chemical water quality determined the fish compositions of trophic guilds (omnivore vs. insectivore sp.) and tolerance guilds (tolerant vs. sensitive sp.) in the basin of the Dongjin River. Thus, ecological stream health at all sites in the Jeongeup Stream, Dongjin River, and Gobu Stream was judged as "poor" to "very poor" conditions by the criteria of An et al. (2002). Especially, the model values of IBI, based on fish assemblages, were lower in the downstreams, compared to the upstreams, indicating an influence of sewage wastewater plants and nutrient runoff from the arable lands. Thus, ecological health, based on a multi-metric fish IBI model, was a positive functional relation with percent forest cover and a negative functional relation with percent arable land. Also, nutrient enrichments $(\mathrm{N}, \mathrm{P})$ and organic matter pollution resulted in degradations of the ecological health (IBI). We believe that the impairments of stream health in the basin were mainly attributed to the runoff from the arable land, sewages from the residential sub-urban area, and effluents from the Jeongeup industrial complex. Efficient watershed managements, therefore, are required in the basin for continual maintaining of water quality and ecological stream health. 


\section{Acknowledgements}

This research was supported by the Basic Science Research Program of the National Research Foundation of Korea (NRF, no. 2013R1A1A4A01012939), and the Daejeon Green Environment Center under the Research Development Program (year 2009); thus, the authors would like to acknowledge these institutions for their assistance.

\section{Authors' contributions}

KG got a project from CNU and designed the experiments. GS analyzed the data and wrote the paper with KG. Both authors read and approved the final manuscript.

\section{Competing interests}

The authors declare that they have no competing interests.

\section{Author details}

'Department of Biological Science, Chungnam National University, Daejeon 34134, South Korea. ${ }^{2}$ Chungnam Girls' High School, Daejeon 34849, South Korea.

Received: 2 February 2016 Accepted: 1 July 2016

Published online: 24 October 2016

\section{References}

An, K. G. \& Kim, J. H. (2005). A diagnosis of ecological health using a physical habitat assessment and multimetric fish model in Daejeon Stream. Korean Journal of Limnology, 38, 361-371.

An, K. G., Lee, J. Y., Bae, D. Y., Kim, J. H., Hwang, S. J., Won, D. H., Lee, J. K., \& Kim, C. S. (2006). Ecological assessments of aquatic environment using multi-metric model in major nationwide stream watersheds. Journal of Korean Society on Water Quality, 22, 796-804.

An, K. G., Park, S. S., \& Shin, J. Y. (2002). An evaluation of a river health using the index of biological integrity along with relations to chemicals and habitat conditions. Environment International, 28, 411-420.

Barbour, M. T., Gerritsen, J., Snyder, B. D., \& Stribling, J. B. (1999). Rapid bioassessment protocols for use in streams and wadeable rivers: periphyton, benthic macroinvertebrates and fish (secondth ed.)

Debora, F. N., Royer, T. V., \& David, M. B. (2006). Controls on chlorophyll-a in nutrient-rich agricultural streams in Illonois, USA. Hydrobiologia, 568, 287-298.

Desirree, D. T., David, L. P., \& Gregory, D. J. (2006). Development and application of a bioindicator for benthic habitat enhancement in the North Carolina Piedmont. Ecological Engineering, 27, 228-241.

Hughes, R. M., \& Gammon, J. R. (1987). Longitudinal changes in fish assemblages and water quality in the Willamette river, Oregon. Transactions of the American Fisheries Society, 116, 196-209.

Jung, S. M., Jang, C. W., Kim, J. K., \& Kim, B. C. (2009). Characteristics of water quality by storm runoffs from intensive highland agriculture area in the upstream of Han River Basin. Journal of Korean Society on Water Environment, 25, 102-111.

Karr, J. R., Fausch, K. D., Angermeier, P. L., Yant, P. R., \& Schlosser, I. J. (1986). Assessing biological integrity in running water: a method and its rationale (p. 28).

Karr, J. R. (1981). Assessment of biotic integrity using fish communities. Fisheries, $6,21-27$

Kim, J. R., \& Lee, C. L. (2001). Ichthyofauna and fish community from the Dongjin River system, Korea. Korean Journal of Ichthyology, 13, 40-49.

Kim, Y. P., Lee, E. H., \& An, K. G. (2009). Ecological health assessment of Dongjin River based on chemical measurement and fish assemblage analysis. Korean Journal of Limnology, 42, 183-191.

Ko, J. W., Jeong, S. T., Kim, C., \& Cho, H. Y. (2001). Analysis of the watershed information and pollutants load using GIS in Mankyung and Dongjin rivers. Journal of Korean Society of Coastal and Ocean Engineers, 13, 237-244.

Lee, J. S., Jung, G. B., Kim, J. H., Yun, S. G., Kim, W. I., \& Shin, J. D. (2004). Evaluation of water quality with $\mathrm{BOD}$ at Mankyeong and Dongjin River basins. Korean Journal of Environmental Agriculture, 23, 81-84.

Lee, K. B., Kim, J. C., Kim, J. G., Lee, D. B., Park, C. W., \& Kim, J. D. (2005). Assessment of pollutant loads in the Dongjin River. Korean Journal of Environmental Agriculture, 24, 91-97.

Lee, Y. S., \& Shin, S. H. (2013). Effective reservoir management methods using nutrients leaching characteristic analysis: case study of the Hongdong Reservoir. Journal of Engineering Geology, 23, 95-104.
Morley, S. A., \& Karr, J. R. (2002). Assessing and restoring the health of urban streams in the Puget sound basin. Conservation Biology, 16, 1498-1509.

Sanders R. E., Milter R. J., Yondr C. O., \& Rankin E. T. (1999). The use of external deformities, erosion, lesions, and tumors (DELT anomalies) in fish assemblages for characterizing aquatic resources: a case study of seven Ohio streams. In T. P. Simon (Eds), Assessing the sustainability and biological integrity of water resources using fish communities (p. 225-245). New York, USA: CRC Press.

Seo, H. J., Chung, S. W., Park, M. O., \& Lee, B. R. (2001). A study on the runoff characteristics and water quality management of Seung-Gi stream area. Clean Technologies, 7, 251-263.

Seong, J. U., \& Park, J. C. (2012). Effects of sewage effluent in organic matters of Nakdong River: comparison of dally loading. Korean Journal of Limnology, $45,210-217$

Son, J. G., Son, T. H., Choi, J. K., Jo, J. Y., Goh, N. Y., \& Oh, J. H. (2012). Monitoring of hydrological and water quality in Dongjin-River Hengjeong Bridge watershed for agricultural watershed non-point pollutant sources management. Journal of The Korean Society of Agricultural Engineers, 54, 55-63.

Uhm, M. J., Choi, J. S., Han, S. G., Kim, K. C., \& Moon, Y. H. (2000). Irrigation water qualities along Dong-Jin River watershed during 1994-1998. Korean Journal of Environmental Agriculture, 19, 110-115.

US EPA. (1993). Fish field and laboratory methods for evaluating the biological integrity of surface waters (pp. 128-198).

Walton, B. M., Salling, M., Wyles, J., \& Wolin, J. (2007). Biological integrity in urban stream: toward resolving multiple dimensions of urbanization. Landscape and Urban Planning, 79, 110-123.

Won, C. H., Jeong, P. J., Kim, M. J., Cho, S. Y., Kim, S. H., \& Kim, J. C. (2002). Investigation on non-point source of Dongjin river basin. Research Engineering, 33, 13-20.

Yeom, D. H., An, K. G., Hong, Y. P., \& Lee, S. K. (2000). Assessment of an index of biological integrity (IBI) using fish assemblages in Keum-Ho River, Korea. Korean Journal of Environmental Biology, 18, 215-226.

Yun, S. G., Kim, Y. I., Kim, J. H., Kim, S. J., Koh, M. H., \& Eom, K. C. (2002). Evaluation of water quality characteristics on tributaries of Dongjin River watershed. Korean Journal of Environmental Agriculture, 21, 243-247.

\section{Submit your next manuscript to BioMed Central} and we will help you at every step:

- We accept pre-submission inquiries

- Our selector tool helps you to find the most relevant journal

- We provide round the clock customer support

- Convenient online submission

- Thorough peer review

- Inclusion in PubMed and all major indexing services

- Maximum visibility for your research

Submit your manuscript at www.biomedcentral.com/submit
Biomed Central 